Article

\title{
Effects of Heavy Metals on Phyllosphere and Rhizosphere Microbial Community of Bothriochloa ischaemum
}

\author{
Tong Jia *, Tingyan Guo, Miaowen Cao and Baofeng Chai \\ Institute of Loess Plateau, Shanxi University, Taiyuan 030006, China; tingyan1995@sina.com (T.G.); \\ caomw1993@163.com (M.C.); bfchai@sxu.edu.cn (B.C.) \\ * Correspondence: jiatong@sxu.edu.cn; Tel.: +86-155-1369-4458
}

Received: 26 July 2018; Accepted: 18 August 2018; Published: 21 August 2018

Featured Application: This study can provide scientific reference for screening dominant combinations of bacterial communities as well as for improving plant-microbial remediation efficiency.

\begin{abstract}
Copper mining has resulted in severe damage to the ecological environment of mining areas. This study investigated heavy metal distribution in plants and compared the driving factors between aboveground and subsurface microorganisms, as well as the diversity in rhizosphere and non-rhizosphere soil microbial community response to heavy metal transfer factors in a copper tailings dam. We analyzed phyllosphere and soil microbial community using high-throughput sequencing and denaturing gradient gel electrophoresis, respectively. Although we detected chromium in aboveground and subsurface of Bothriochloa ischaemum specimens, no chromium was detected in soil. Total nitrogen was negatively correlated to the carbon and nitrogen ratios of plants and soil, respectively, while the total sulfur was negatively correlated to cadmium in roots. On the contrary, soil sulfur was positively correlated to cadmium in soil. Moreover, soil sulphur was the main influencing factor on the soil bacterial community, while ammonium nitrogen, total nitrogen, and zinc were the driving factors of fungi diversity in non-rhizosphere soil. Fungi diversity in the rhizosphere was significantly correlated to phosphatase, and fungi diversity in the non-rhizosphere was significantly correlated to sucrose enzymes. The transfer factor of lead was negatively correlated to rhizosphere fungi diversity, and the transfer factor of copper was significantly correlated to non-rhizosphere bacterial diversity. Results from this study may offer some scientific reference for the improvement of plant-microbe remediation efficiency. At the same time, this study could provide an ecological basis for further studies on soil ecosystem restoration and degradation mechanisms that are associated with copper tailings dams.
\end{abstract}

Keywords: heavy metal; phyllosphere bacteria community; rhizosphere; soil microbial community

\section{Introduction}

Given their high metal content, metal-based tailings are widely considered to have a serious environmental impact [1,2]. China has a considerable number of metal mines that produce extensive waste byproducts, and consequently result in severe environmental pollution [3,4]. Mining activities have also caused considerable damage to the eco-environment. The Zhongtiao Mountains copper mine is the largest underground copper mine in China [3,5]. The mine has an annual output of greater than four million tons of ore [6]. This mine predominately produces copper $(\mathrm{Cu})$ ore, but it also produces other metals, such as iron $(\mathrm{Fe})$, lead $(\mathrm{Pb})$, zinc $(\mathrm{Zn})$, and cadmium $(\mathrm{Cd})$ [7]. During metal mineral 
resource development, a large amount of heavy metals is directly deposited into the soil with waste rocks, tailings, and other mineral dust in mining districts and their surrounding areas, which then become the primary source of environmental pollution [5].

Phytoremediation is regarded as one of the most effective methods in reducing the environmental risk from tailings [8]. This remediation approach either removes pollutants or degrades them into less harmful constituents by using the metabolic activities of plants. On the other hand, it employs plant unique tolerance or accumulation abilities to existent contaminants, and actuating root absorption and the transformation of pollutants, subsequently both reducing the pollutant concentrations and pollutants altogether [9]. At the present time, the phytoremediation method typically selects plants that are resistant to poor soil and heavy metals, such as Isocoma veneta (Kunth) Greene, Teloxys graveolens (Willd.) Weber [10], Bidens humilis [11], Atriplex lentiformis (Torr.) S. Wats. [12], Lygeum spartum L., and Piptatherum miliaceum (L.) Coss [13], which can grow normally on lead-zinc deposits and copper tailings from mine extraction. Thlaspi calaminare, a recognized hyperaccumulator, has a strong $\mathrm{Zn}$ and Cd heavy metal absorption capacity [11].

In recent years, plant-microbial remediation has gradually gained considerable attention [14-16]. The mutualistic symbiosis between microorganisms and plants do not only stimulate plant growth, it promotes water and nutrient absorption capacities, increases plant biomass, strengthens plant tolerance to heavy metals, and enhances the plant absorption capacities of heavy metals, thus improving the overall ability of the phytoremediation method [17]. Both plants and soil microbes are capable of remediating heavy metals; therefore, the combination of microbe and plant remediation has a tremendous application potential in improving the absorption and transformation efficiency of heavy metals in the soil profile [2,7].

On the one hand, soil microbial community remediation is one of the primary means of ecosystem rehabilitation and sustainability within mining areas, because most of these areas are subject to contamination [18]. Soil microorganisms, which are involved in many biochemical processes, such as the promotion of ecosystem material circulation, energy flow, organic matter decomposition, and soil nutrient transportation, are the repository of soil nutrients and a source of available nutrients for plant growth. They can also be used as key performance indicators for biological effectiveness of soil fertility and nutrient resources. Soil microbial activity and structure vary under the different rehabilitation methods and their respective time allotments [19-21]. Moreover, different reclamation scenarios have been reported to play a role in determining soil microbial abundance, diversity, and composition [22]. Cheng et al. found that forest types are significantly affected by soil microbial properties due to differences in soil physicochemical features [23].

On the other hand, the rhizosphere is a hotspot for microbial interactions given that exudates that are released by roots are the main nutrient source for microorganisms as well as a driving force behind their population density and activities [24,25]. Root exudates can promote heterotrophic growth, which can lead to local competition for inorganic nutrients between roots and microorganisms [24,26]. Moreover, root-associated microbial communities play a vital role in soil ecosystems, influencing many soil biochemical processes and impacting plant growth and health [27]. Non-rhizosphere soil is either not or only slightly affected by roots and root exudates; thus, this soil zone has a lower level of microbial activity and soil fertility. Nonetheless, non-rhizosphere soil is necessary for the stability of soil aggregates as well as the resistance of soil erosion and nutrient leaching [28].

Although many studies have shown that anthropogenic activities result in changes to the soil microbial structure of both the rhizosphere and non-rhizosphere, few studies have investigated phyllosphere microorganisms in copper tailings dams. Aerial components of living plants, including leaves, stems, buds, flowers, and fruits, provide a habitat for microorganisms, and these habitats are collectively referred to as the phyllosphere [29]. Bacteria are considered to be the dominant microbial inhabitants of the phyllosphere, but archaea, filamentous fungi, and yeasts may also be important inhabitants [29]. It has been shown that bacterial communities in the phyllosphere are able to promote plant growth [30,31] and increase plant resistance to pathogens [32,33]. A previous study 
showed that endophyte infection rates of Bothriochloa ischaemum and Festuca rubra could be used as indicators of $\mathrm{Cd}$ pollution levels, and fungal endophytes that are associated with Imperata cylindrical and Elymus dahuricus developed a certain tolerance to $\mathrm{Pb}[5]$.

There have been a few studies to date conducted on the distribution of heavy metals in plants and a comparison of the driving factors between aboveground and subsurface microorganisms in copper tailings dams. Furthermore, a comprehensive comparison between soil microbial communities and the response of physicochemical properties to heavy metal pollution is extremely limited in the literature. In this study, we investigated plant and soil physicochemical properties and their respective microbial abundance and diversity in the no. 536 sub-dams of the Zhongtiao Mountains copper mine, after being subjected to 19 years of remediation. We accomplished this by addressing the following questions: (1) What are the driving factors of the distribution of heavy metals on the aboveground and subsurface B. ischaemum microbial communities in a copper tailings dam? (2) What is the correlation among plant and soil physicochemical properties, heavy metals, their transfer factors, and soil enzymes? (3) What are the main factors that affect bacterial flora in phyllosphere, rhizosphere, and non-rhizosphere soil microbial communities? The objectives of this study were to understand the potential ecological function of $B$. ischaemum as it relates to heavy metal accumulation in a copper tailings dam, and to evaluate the driving factors that affect bacterial community structure and the diversity of $B$. ischaemum. This study can provide scientific reference for screening dominant combinations of bacterial communities as well as for improving plant-microbial remediation efficiency.

\section{Materials and Methods}

\subsection{Site Description}

The 'eighteenth' river tailing of the Northern Copper Mine $\left(35^{\circ} 15^{\prime} \sim 35^{\circ} 17^{\prime} \mathrm{N}, 118^{\circ} 38^{\prime} \sim 111^{\circ} 39^{\prime} \mathrm{E}\right)$ was constructed in 1969, which lies in the south of Shanxi province, China. The waste from mineral processing is accumulated in the form of ore sand every year in the 'eighteenth' river tailings. A new sub-dam is formed on the basis of original sub-dam every three to five years, and then covered $30 \mathrm{~cm}$ native soil on ore surface. The elevation of dam base and dam crest is $486 \mathrm{~m}$ and $509 \mathrm{~m}$, respectively. At this point in time, it is composed of 14 sub-dams, with a stack height of $84 \mathrm{~m}$ and a texture ratio of 1:6. It is under the influence of a continental monsoon climate with four distinct seasons, where the annual mean temperature is $14^{\circ} \mathrm{C}$, annual precipitation is approximately $780 \mathrm{~mm}$, and frost free days are greater than $200 \mathrm{~d}$ [34].

\subsection{Plant and Soil Sampling}

In July 2016, we selected No.536 sub-dam with 19 restoration years for sampling. The dominant species was $B$. ischaemum in this sub-dam. Five plots $(1 \mathrm{~m} \times 1 \mathrm{~m})$ were randomly selected as sample collection area. In each plot, 16 individuals from each natural grass species were selected and quickly sealed the leaves into sterile plastic bags using ethanol sterilized tweezers. One subsample was stored at envelope bag to determine physiochemical properties, and the other was placed in an icebox and taken to the lab to be stored at $-20{ }^{\circ} \mathrm{C}$ prior to high-throughput sequencing. Correspondingly, we also collected rhizosphere and soil samples from the soil organic layer (from $0 \mathrm{~cm}$ to $5 \mathrm{~cm}$ depths directly below the litter layer) at this plot while using a sterile spade. Visible roots and residues were removed prior to the homogenization of the soil fraction of each sample. Fresh soil samples were filtered through a $2 \mathrm{~mm}$ sieve and then divided into two subsamples. One subsample was stored at $4{ }^{\circ} \mathrm{C}$ to determine the physiochemical properties, while the other was stored at $-20{ }^{\circ} \mathrm{C}$ prior to DNA extraction.

\subsection{Plant and Soil Chemical Properties}

We measured total carbon (C), total nitrogen $(\mathrm{N})$, and total sulfur (S) content of plant and soil while using the elemental analyzer (vario EL/MACRO cube, Elementar, Hanau, Germany). Heavy metals 
(As, $\mathrm{Cd}, \mathrm{Cu}, \mathrm{Pb}, \mathrm{Zn}$ ) contents of plant and soil were measured while using an ICP-AES (iCAP 6000, Thermo Fisher, Cambridge, UK) [6]. Soil pH was measured after shaking soil water (1:2.5 mass/volume) suspensions for $30 \mathrm{~min}$. Soil moisture was measured gravimetrically. Soil particle size was measured while using a Mastersizer 3000 laser diffraction particle size analyzer (Malvern Instruments Ltd., Malvern, UK). We measured soil ammonium nitrogen $\left(\mathrm{NH}_{4}{ }^{+}-\mathrm{N}\right)$, nitrate nitrogen $\left(\mathrm{NO}_{3}{ }^{-}-\mathrm{N}\right)$, nitrite nitrogen $\left(\mathrm{NO}_{2}{ }^{-}-\mathrm{N}\right)$, and Olsen $\mathrm{P}$ while using the Automatic Discrete Analyzer (CleverChem 380, DeChem-Tech. GmbH, Hamburg, Germany). For plant and soil chemical properties, we conducted five repetitions in this sub-dam. Additionally, soil sucrase was measured using 3,5-Dinitrosalicylic acid colorimetry; phenol-sodium hypochlorite colorimetry was used in urease; catalase was determined by potassium permanganate titration; and, phosphatase was determined by the disodium phenyl phosphate colorimetric method [35,36].

\subsection{Determination of Phyllospheric Bacterial Community Structure}

Five tillers were randomly collected from each plant, and the outermost non-senescent leaf sheath of each tiller was used in this assay. A strip of epidermis was peeled from the inner surface of the leaf sheath close to the stem base. The strip was placed on a slide, mounted in aniline blue stain, and the slide was heated over a flame until the stain reached the boiling point. It was then examined for hyphae under $\times 400$ magnification. Microbial DNA from the four natural grass species samples was extracted while using the E.Z.N.A. ${ }^{\circledR}$ Soil DNA Kit (Omega Bio-tek, Inc., Norcross, GA, USA), according to the manufacturer's protocols. The V4-V5 region of the bacterial $16 \mathrm{~S}$ ribosomal RNA ( $r R N A$ ) genes was amplified using primers 515F 5'-barcode-GTGCCAGCMGCCGCGG)-3' and 907R 5'-CCGTCAATTCMTTTRAGTTT-3', where the barcode was an eight-base sequence that was unique to each sample. For this study, we sent plant samples to the Lingen Biotechnology Co., Ltd. (Shanghai, China) for high-throughput sequencing.

\subsection{DNA Extraction, Polymerase Chain Reaction, and Denaturing Gradient Gel Electrophoresis}

Total soil DNA was extracted while using the E.Z.N.A. ${ }^{\circledR}$ Soil DNA Kit (Omega Bio-Tek, Inc., Norcross, GA, USA). The quality and quantity of DNA extracts were measured using the Plate reader Infinite 200 PRO (TECAN, Switzerland). DNA purity was assessed by the determination of the A260/A280 absorbance ratios, and only DNA extracts with absorbance ratios of 1.8-2.0 were used for bacterial community analyses [37].

The structure of the bacterial and fungal communities was evaluated using denaturing gradient gel electrophoresis (DGGE), as follows: partial 16S rRNA genes were amplified by PCR with DNA template concentrations of $10 \mathrm{ng} / \mu \mathrm{L}$. Fragments of $16 \mathrm{~S} r R N A$ genes (the $\mathrm{V} 3$ region) were amplified by PCR using primers 341F (5'-CGC CCG CCG CGC GCG GCG GGC GGG GCG GGG GCA CGG GGG GCC TAC GGG AGG CAG CAG-3'), 534R (5'-ATT ACC GCG GCT GCT GG-3'). Hot start PCR was as follows: $95^{\circ} \mathrm{C}$ for $4 \mathrm{~min}$, followed by 30 cycles at $94{ }^{\circ} \mathrm{C}$ for $40 \mathrm{~s}$, annealing at $63.5^{\circ} \mathrm{C}$ for $30 \mathrm{~s}$, extension at $72{ }^{\circ} \mathrm{C}$ for $30 \mathrm{~s}$, and $72{ }^{\circ} \mathrm{C}$ for $10 \mathrm{~min}$.

Partial $18 \mathrm{~S} r R N A$ genes were amplified by PCR with DNA template concentrations of $10 \mathrm{ng} / \mu \mathrm{L}$. Fragments of $18 \mathrm{~S} r R N A$ genes (the V4 region) were amplified by PCR using primers FUNG-GC (5'-CGC CCG CCG CGC CCC GCG CCC GGC CCG CCG CCC CCG CCC CAT TCC CCG TTA CCC GTT G-3'), NS1 (5'-GTA GTCA TAT GCT TGT CTC-3'). Hot start PCR was as follows: $95^{\circ} \mathrm{C}$ for $5 \mathrm{~min}$, followed by 30 cycles at $94{ }^{\circ} \mathrm{C}$ for $30 \mathrm{~s}$, annealing at $53{ }^{\circ} \mathrm{C}$ for $30 \mathrm{~s}$, extension at $72{ }^{\circ} \mathrm{C}$ for $30 \mathrm{~s}$, and $72{ }^{\circ} \mathrm{C}$ for $7 \mathrm{~min}$.

\subsection{Denaturing Gel Gradient Electrophoresis Analysis}

The DGGE runs were performed using a DCode system (Bio-Rad Laboratories, Inc., Hercules, CA, USA). $8 \mu \mathrm{L}$ bacteria PCR products were loaded onto $10 \%(w / v)$ polyacrylamide gels over a urea gradient between $45 \%$ and $65 \%$ (urea and formamide). $8 \mu \mathrm{L}$ fungi PCR products were loaded onto $8 \%$ $(w / v)$ polyacrylamide gels over a urea gradient that was between $25 \%$ and $35 \%$ (urea and formamide). 
Electrophoresis was run for $12 \mathrm{~h}$ at $65 \mathrm{~V}$. The comb of this system to load samples can only have up to 20 holes. Gels were then stained using the silver staining method [38], and then photographed on a Gel imaging system (GelDoc XR, Biorad, Hercules, CA, USA). DGGE images analysis of the band profiles were carried out using Quantity one 4.62 (Biorad, Hercules, CA, USA), which detected bands and quantifies the relative concentration of DNA. The number of distinct DGGE bands was used as an estimate of species richness and the relative abundance of each band was treated as the proportion of a given species within a sample.

\subsection{Statistical Analysis}

Significant differences between variables of plant and soil were analyzed by One-way anova and Duncan's Multiple Range test (DMRT). Pearson correlation was used to analyze the relationship between plant properties and heavy metals, as well as soil physicochemical properties and microbial diversity. Transfer factors of different heavy metals were calculated by the ratio of shoot heavy metal to root heavy metal. The number of distinct DGGE bands was imported into SPSS v20.0 (International Business Machines Corporation, Chicago, IL, USA) in order to calculate the Shannon-Wiener index, Margalef, Evenness, and Simpson index [39].

\section{Results}

\subsection{Physiological Characteristics and Heavy Metal Distribution of B. ischaemum}

Our results showed no significant differences between the root and shoot of B. ischaemum total nitrogen, total carbon and total sulfur content. Contrary, the carbon nitrogen ratio (55.09 \pm 6.87$)$ of root was significantly higher than the carbon nitrogen ratio of shoot (38.87 \pm 3.71 ) (Figure 1). The nutrient element content (total carbon, total nitrogen, and total sulfur) in the shoot was significantly higher than that in soil (Figure 1). The distributions of heavy metals indicated that content of arsenic (As, $25.4 \mathrm{ppm}$ ) and cadmium (Cd, $6.3 \mathrm{ppm})$ in the soil was higher than the As (1.2 ppm) and Cd (2.4 ppm) in B. ischaemum (Figure 2). The copper content $(\mathrm{Cu}, 352.8 \mathrm{ppm}$ ) in soil was also higher than that in above- and underground of $B$. ischaemum. There was no significant difference in the distribution of $\mathrm{Pb}$ and $\mathrm{Zn}$ in the root, shoot, and soil. We found that $\mathrm{Cr}$ was detected only on the above- and underground of $B$. ischaemum, but no $\mathrm{Cr}$ was detected in the soil. In particular, the $\mathrm{Cr}$ content (982.6 ppm) in the root of B. ischaemum was higher than in the shoot (387.7 ppm), indicating that B. ischaemum had an enrichment effect on $\mathrm{Cr}$, especially the root had a strong ability of enrichment for $\mathrm{Cr}$.
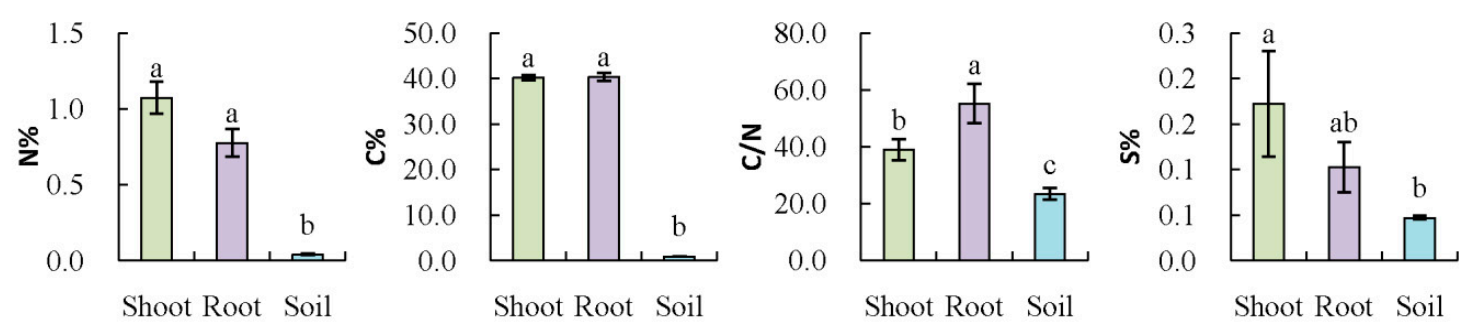

Figure 1. Mean $( \pm S E)$ of total nitrogen $(N)$, total carbon $(C)$, ratio of carbon and nitrogen $(C / N)$, and total sulphur (S) in shoot, root, and soil of B. ischaemum. Different letters indicate significant differences according to Duncan's test $(P<0.05)$. 


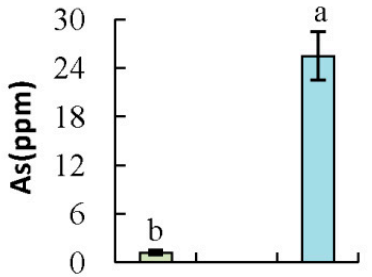

Shoot Root Soil

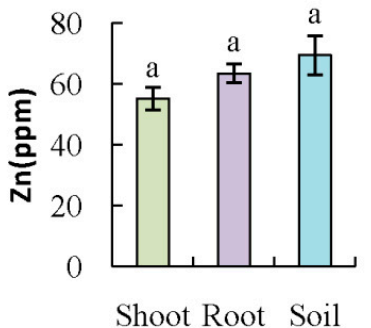

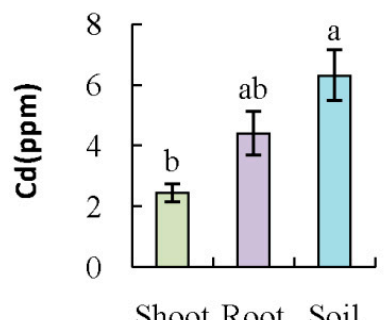

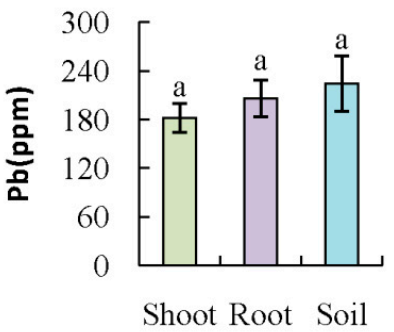

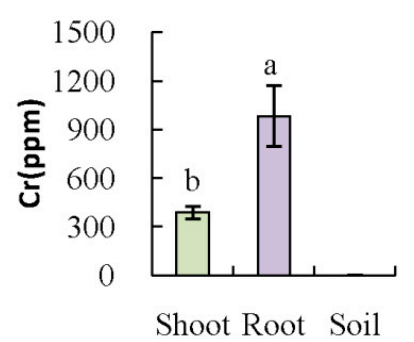

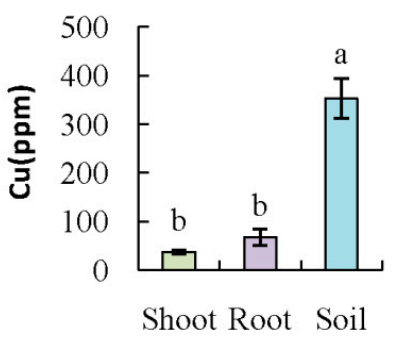

Figure 2. Heavy metal allocation in shoot, root, and soil of $B$. ischaemum. Different letters indicate significant differences according to Duncan's test $(P<0.05)(a>a b>b>c)$.

\subsection{Correlations among B. ischaemum Soil Physicochemical Characteristics and Heavy Metals}

The total carbon content was negatively correlated with the $\mathrm{Cu}$ content in shoot of $B$. ischaemum $(\mathrm{r}=-0.964, P<0.01)$. In addition to $\mathrm{Cu}$, there was no significant correlation between the content of other heavy metals in the ground and the physical and chemical indexes of the leaves (Figure 3). The total nitrogen in shoot was significantly negatively correlated with its ratio of carbon and nitrogen $(\mathrm{r}=-0.979, P<0.01)$ (Figure 3$)$. The total sulfur content in root was negatively correlated with cadmium content in root $(\mathrm{r}=-0.899, P<0.05)$, except for cadmium, there was no significant correlation between heavy metals in the root and soil physicochemical properties (Figure 3). In addition, the total nitrogen of root was significantly negatively correlated with the root carbon and nitrogen ratio $(\mathrm{r}=-0.979, P<0.01)$ (Figure 3).

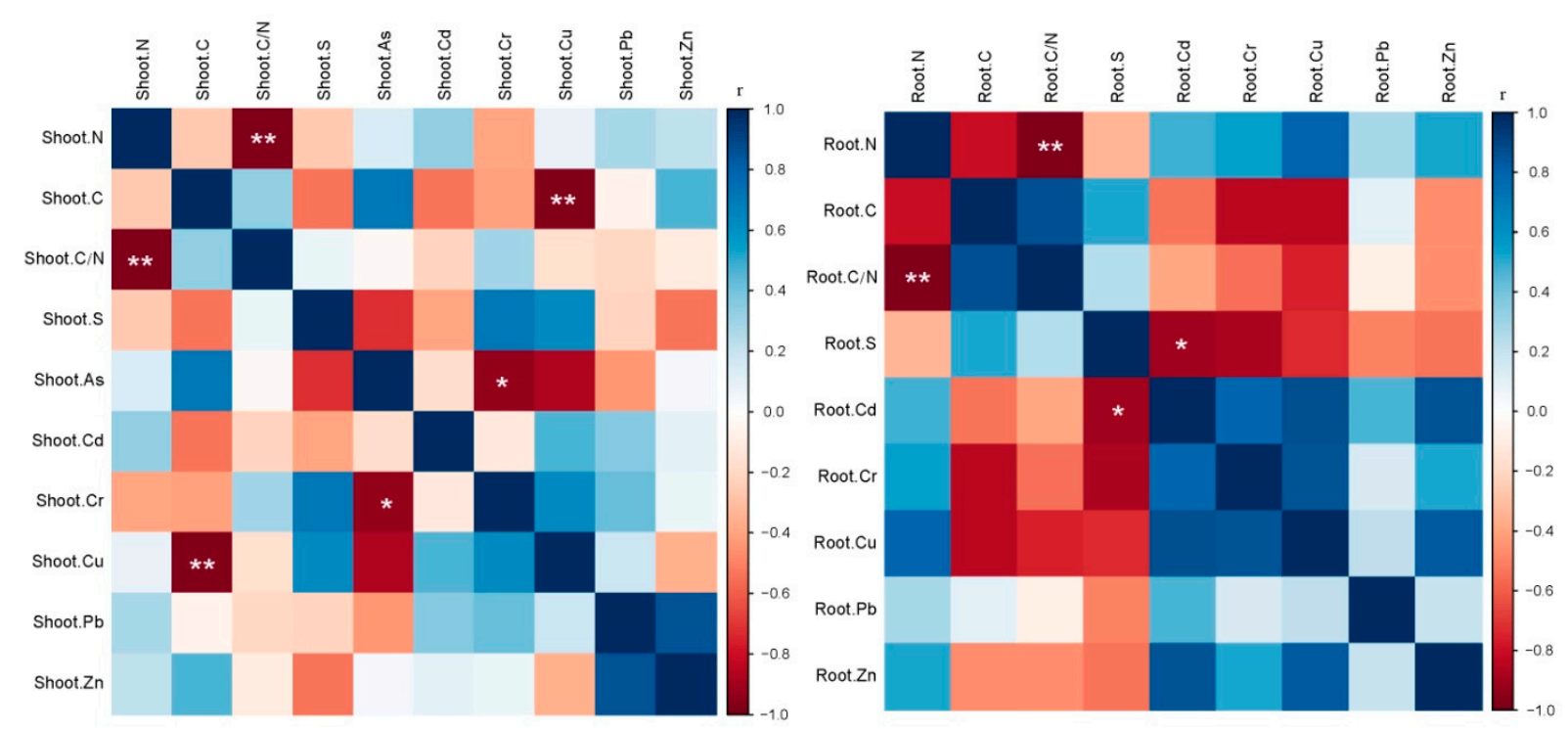

Figure 3. The Pearson correlations among shoot and root chemical properties and their heavy metal contents of $B$. ischaemum. Shoot and root chemical properties include total nitrogen $(\mathrm{N})$, total carbon $(C)$, total sulphur $(S)$, and ration of carbon and nitrogen $(\mathrm{C} / \mathrm{N}) .{ }^{* *}$ Correlation is significant at the 0.01 level (2-tailed), * Correlation is significant at the 0.05 level (2-tailed). 
The results showed that soil nitrate nitrogen was negative correlation with As $(\mathrm{r}=-0.880$, $P<0.05)$, however, soil total nitrogen also showed a significant positive correlation with soil zinc $(\mathrm{r}=0.945, P<0.05)$. In addition, the average particle size of soil was significantly negatively correlated with soil total carbon $(r=-0.930, P<0.05)$, while soil nitrate nitrogen and total nitrogen content of present positively correlated $(r=0.891, P<0.05)$, and soil total nitrogen was significantly negatively correlated with the ratio of soil carbon and nitrogen (Figure 4). The soil sulfur was significant positive correlated with urease, while $\mathrm{Cu}$ in soil was negatively correlated with catalase and urease. The $\mathrm{C} / \mathrm{N}$ was positive correlated with sucrase, but negatively correlated with phosphatase (Figure 4). It can be seen that the soil physical and chemical properties affect the content of heavy metals and soil enzymes in soil.

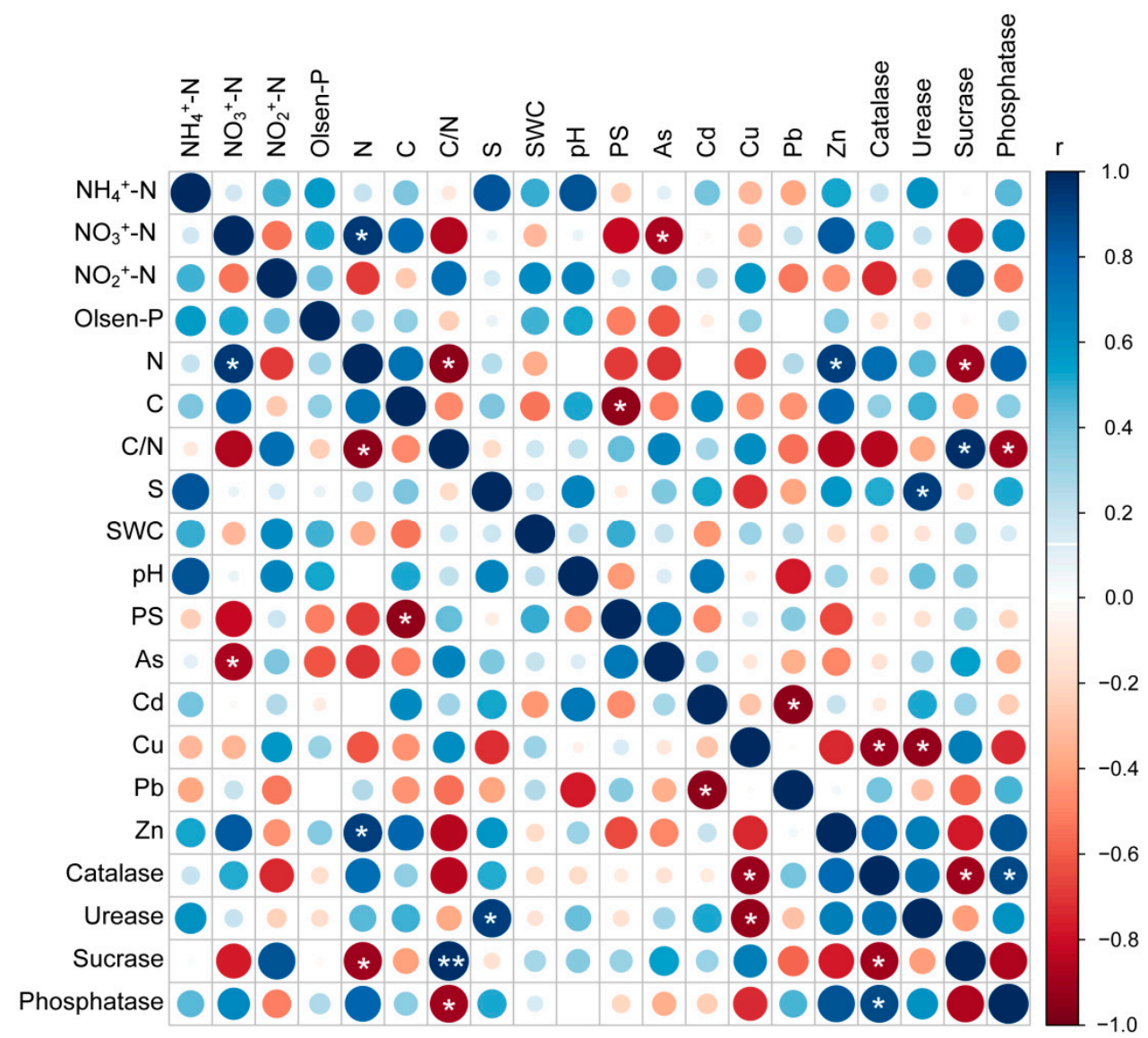

Figure 4. The Pearson correlations among soil physicochemical properties, soil heavy metals and soil enzymes in non-rhizophere soil. Physical and chemical properties of soil included total nitrogen (N), total carbon $(\mathrm{C})$, total sulphur $(\mathrm{S})$, ration of carbon and nitrogen $(\mathrm{C} / \mathrm{N})$, soil water content (SWC), soil $\mathrm{pH}$, particle size (PS), ammonium nitrogen $\left(\mathrm{NH}_{4}{ }^{+}-\mathrm{N}\right)$, nitrate nitrogen $\left(\mathrm{NO}_{3}{ }^{-}-\mathrm{N}\right)$, nitrite nitrogen $\left(\mathrm{NO}_{2}{ }^{-}-\mathrm{N}\right)$, and Olsen-P. ${ }^{*}$ Correlation is significant at the 0.05 level (2-tailed).

\subsection{B. ischaemum Phyllosphere Bacteria Community Structure and Diversity}

We found 35630 high quality bacterial 16S $r R N A$ gene sequences with an average sequence length of $375.23 \mathrm{bp}$. All of the sequences were clustered into 22 different OTUs at $97 \%$ sequence similarity level. Approximately $99.9 \%$ of the sequences were classified into 13 different genera, which could reflect the actual situation of phyllosphere bacteria community structure of $B$. ischaemum. Shannon-wiener index and Simpson index were used to reflect the microbial diversity of different grasses. Chao 1 index and abundance-based coverage estimator (ACE) index were used to estimate the operational taxonomic 
unit (OTU) numbers in samples. In this study, both Chao 1 index and ACE index of $B$. ischaemum were 22. The Shannon-wiener index was 0.74 and the Simpson index was 0.566 .

Phyllosphere dominant bacteria at the class level were Gammaproteobacteria, and $(45.45 \%$ of relative abundance), followed by Mollicutes (22.73\%), Alphaproteobacteria (13.64\%), and Betaproteobacteria $(9.09 \%)$ (Figure 5a). On the order level, the dominant bacteria of phyllosphere were Pseudomonadales, Enterobacteriales, and Rhizobiales (Figure 5b). On the family level, the dominant bacteria were Pseudomonadaceae, Acholeplasmataceae, and Enterobacteriaceae, and the relative abundance was $22.27 \%, 22.73 \%$, and $13.64 \%$, respectively (Figure 5c). Pseudomonas and Phytoplasma were the predominant bacteria of phyllosphere at genus level (Figure $5 \mathrm{~d}$ ).

(a) Class

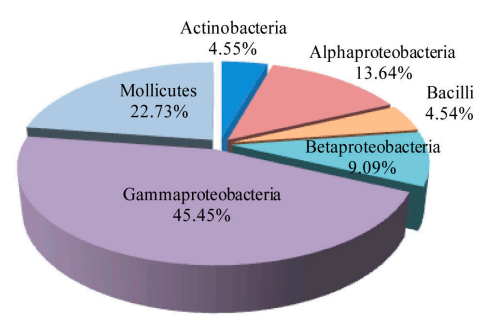

(c) Family

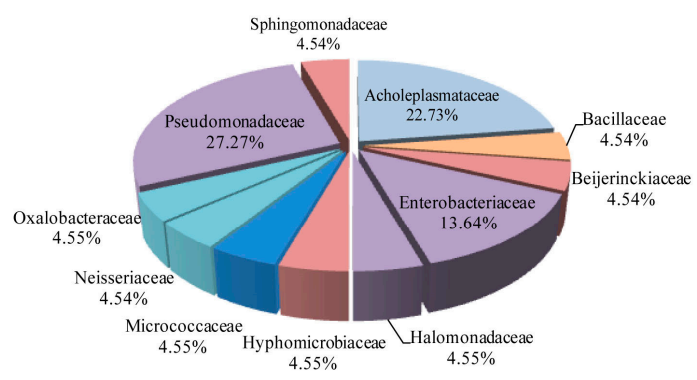

(b) Order

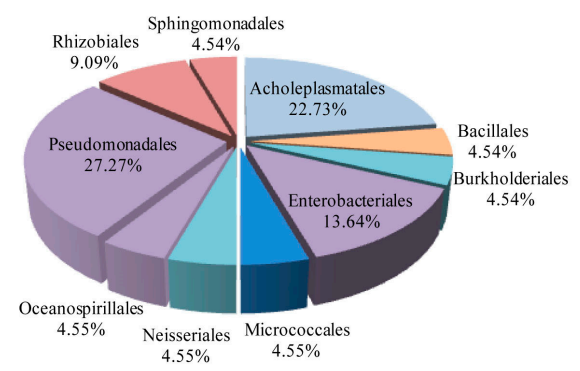

(d) Genus

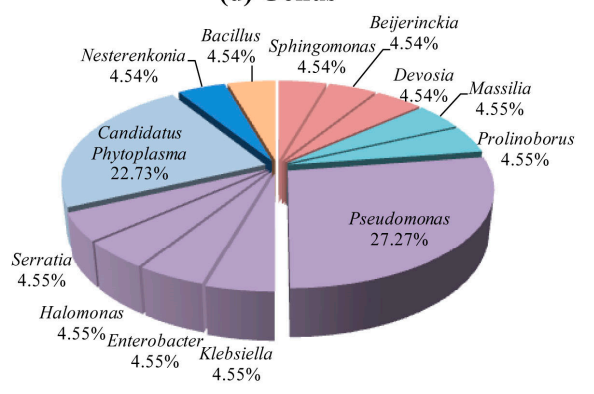

Figure 5. Different levels of relative abundances of B. ischaemum phyllosphere bacteria. (a) Class; (b) Order; (c) Family; and, (d) Genus.

\subsection{Bacterial Diversities of Rhizosphere and Non-Rhizosphere Soil and Their Driving Factors}

There were no significant differences between the rhizosphere and non-rhizosphere bacterial and fungal diversity of $B$. ischaemum, by DGGE, respectively (Table 1 ). The copy numbers of bacterial genes in non-rhizosphere soil (8.0 log copies $\mathrm{g}^{-1} \mathrm{dw}$ soil) was significantly higher when compared with rhizosphere soil ( $6.7 \mathrm{log}$ copies $\mathrm{g}^{-1} \mathrm{dw}$ soil). However, the copy numbers of fungi genes in rhizosphere soil was significantly higher than non-rhizosphere soil (Figure 6). By analyzing the relationship between the root properties of $B$. ischaemum and diversity of rhizosphere soil bacterial community, our results showed that $\mathrm{Cd}$ in root was positively correlated with the rhizosphere soil bacteria richness index (Margalef index) (Table S1). The correlation between soil physicochemical properties and the diversity of non-rhizosphere soil bacteria community showed that soil sulfur content significantly affected Shannon-wiener index, species richness, and Margalef and Simpson index of the soil bacterial community. Moreover, soil sulfur was significantly positively correlated with Shannon-wiener index, Simpson index, species richness, and Margalef (Table S2). Similarly, Cd content also had significant positive correlation with the Shannon-wiener index and Simpson index of bacteria (Table S2). For non-rhizophere soil fungi community, the ammonium nitrogen, total nitrogen, and $\mathrm{Zn}$ were positively correlated with the diversity of non-rhizosphere soil fungi, but $\mathrm{C} / \mathrm{N}$ was significantly negatively correlated with its diversity (Table S2). 
Table 1. Mean ( \pm SD) diversity indices of microbial community in rhizosphere and non-rhizophere soil.

\begin{tabular}{|c|c|c|c|c|c|c|}
\hline & & $S$ & $\mathrm{H}^{\prime}$ & $d_{\operatorname{Max}}$ & $E_{n}$ & $D$ \\
\hline \multirow{2}{*}{ Bacteria } & Non-rhizosphere & $35.80 \pm 3.834^{\mathrm{a}}$ & $3.550 \pm 0.105^{a}$ & $4.102 \pm 0.402^{\mathrm{a}}$ & $0.994 \pm 0.007^{\mathrm{a}}$ & $0.971 \pm 0.003^{a}$ \\
\hline & Rhizosphe & $39.40 \pm 1.673^{a}$ & $3.633 \pm 0.079^{a}$ & $4.506 \pm 0.164^{a}$ & $0.989 \pm 0.010^{a}$ & $0.973 \pm 0.002^{a}$ \\
\hline \multirow[t]{2}{*}{ Fungi } & Non-rhizosphere & $2.677 \pm 0.248^{b}$ & $15.00 \pm 3.808^{b}$ & $1.814 \pm 0.434^{b}$ & $0.998 \pm 0.001^{\mathrm{ab}}$ & $0.929 \pm 0.017^{b}$ \\
\hline & Rhizosphere & $2.710 \pm 0.227^{b}$ & $15.40 \pm 3.362^{b}$ & $1.858 \pm 0.391^{b}$ & $0.998 \pm 0.001^{b}$ & $0.932 \pm 0.016^{b}$ \\
\hline
\end{tabular}

Note: Abbreviations represent Species richness $(S)$, Shannon-Wiener index $\left(H^{\prime}\right)$, Margalef $\left(d_{M a x}\right)$, and Evenness $\left(E_{n}\right)$, Simpson index $(D)$. Different letters indicate significant differences, according to Duncan's test $(P<0.05)$.

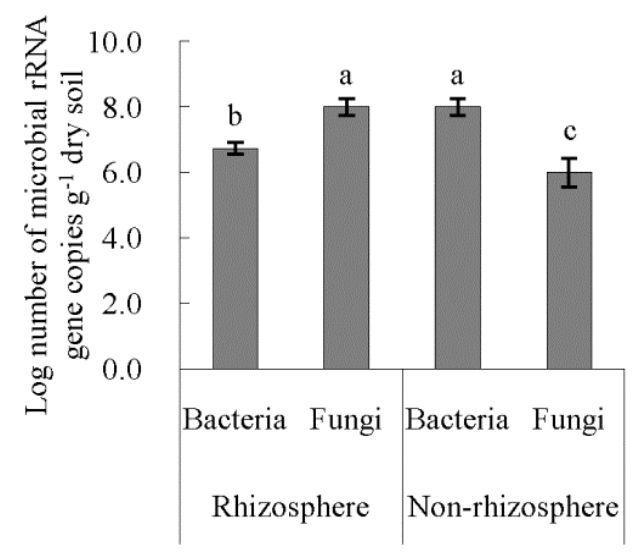

Figure 6. Abundance of rhizosphere and non-rhizophere soil bacteria and fungi $r R N A$ genes in copper tailings dam. The different case letters indicate that the means are significantly different among reclaimed scenario $(P<0.05)$ with Duncan test $(\mathrm{a}>\mathrm{b}>\mathrm{c})$.

\subsection{Relationship between Soil Enzyme Activities and Diversity Indices of Soil Microbial Community}

There was no significant correlation between rhizosphere and non-rhizosphere bacterial diversities and soil enzyme activities (Table 2). However, the rhizosphere fungi diversity was significantly related to phosphatase, and non-rhizosphere fungi diversity was significantly correlated with sucrase enzymes (Table 2). Moreover, the sucrase enzyme was significantly correlated with rhizosphere soil fungi evenness index (Table 2).

Table 2. The Pearson correlations among soil enzyme activities and diversity indices of soil microbial community.

\begin{tabular}{|c|c|c|c|c|c|c|}
\hline & Microb & ersity & Catalase & Urease & Sucrase & Phosphatase \\
\hline \multirow[t]{10}{*}{ Rhizosphere } & Bacteria & $H^{\prime}$ & 0.376 & 0.594 & 0.028 & 0.333 \\
\hline & & $S$ & 0.375 & 0.534 & 0.001 & 0.375 \\
\hline & & $d_{\operatorname{Max}}$ & 0.405 & 0.579 & -0.030 & 0.424 \\
\hline & & $E n$ & 0.376 & 0.656 & 0.052 & 0.289 \\
\hline & & $D$ & 0.346 & 0.573 & 0.061 & 0.299 \\
\hline & Fungi & $H^{\prime}$ & 0.679 & 0.362 & -0.773 & 0.924 * \\
\hline & & $S$ & 0.724 & 0.394 & -0.814 & $0.942 *$ \\
\hline & & $d_{\operatorname{Max}}$ & 0.717 & 0.396 & -0.807 & $0.938 *$ \\
\hline & & $E n$ & -0.738 & -0.218 & $0.913 *$ & -0.890 * \\
\hline & & $D$ & 0.631 & 0.325 & -0.729 & $0.903 *$ \\
\hline \multirow[t]{5}{*}{ Non-rhizosphere } & Bacteria & $H^{\prime}$ & 0.053 & 0.682 & 0.311 & -0.170 \\
\hline & & $S$ & 0.219 & 0.793 & 0.183 & 0.002 \\
\hline & & $d_{\operatorname{Max}}$ & 0.232 & 0.799 & 0.170 & 0.011 \\
\hline & & En & -0.852 & -0.649 & 0.644 & -0.854 \\
\hline & & $D$ & 0.078 & 0.705 & 0.287 & -0.137 \\
\hline
\end{tabular}


Table 2. Cont.

\begin{tabular}{|c|c|c|c|c|c|}
\hline \multicolumn{2}{|c|}{ Microbial Diversity } & \multirow{2}{*}{$\begin{array}{c}\text { Catalase } \\
0.736\end{array}$} & \multirow{2}{*}{$\begin{array}{c}\text { Urease } \\
0.442\end{array}$} & \multirow{2}{*}{$\begin{array}{c}\text { Sucrase } \\
-0.886^{*}\end{array}$} & \multirow{2}{*}{$\begin{array}{c}\text { Phosphatase } \\
0.758\end{array}$} \\
\hline Fungi & $H^{\prime}$ & & & & \\
\hline & $S$ & 0.708 & 0.384 & -0.884 * & 0.739 \\
\hline & $d_{\operatorname{Max}}$ & 0.716 & 0.398 & $-0.887^{*}$ & 0.746 \\
\hline & $E n$ & -0.790 & -0.662 & 0.667 & -0.448 \\
\hline & $D$ & 0.760 & 0.502 & $-0.881 *$ & 0.772 \\
\hline
\end{tabular}

Note: Abbreviations represent Shannon-Wiener index $\left(H^{\prime}\right)$, Species richness $(S)$, Margalef $\left(d_{M a x}\right)$, and Evenness $\left(E_{n}\right)$, Simpson index $(D) .{ }^{*}$ Correlation is significant at the 0.05 level (2-tailed).

\subsection{Transfer Factors of Heavy Metals in B. ischaemum and Their Driving Factors}

Transfer factors of $\mathrm{Pb}$ and $\mathrm{Zn}$ were significantly higher than that of $\mathrm{Cd}$ and $\mathrm{Cr}$ for $\mathrm{B}$. ischaemum (Figure 7). There was no significant correlation between microbial gene copy numbers and transfer factors of heavy metals, but the ratio of rhizosphere bacteria and fungi was significantly positively correlated with transfer factor of $\mathrm{Pb}$ (TF-Pb) (Table 3). TF- $\mathrm{Pb}$ was significantly negatively correlated with phosphatase, and transfer factor of $\mathrm{Zn}(\mathrm{TF}-\mathrm{Zn})$ was significantly negative correlated with urease (Table 4). For the rhizosphere microorganisms, TF-Pb was negatively related to the diversity of rhizosphere fungi, but there was no significant correlation between bacterial diversities and other transfer factors. For non-rhizosphere, the transfer factor of $\mathrm{Cu}(\mathrm{TF}-\mathrm{Cu})$ was significantly correlated with bacterial diversity, and there was no significant correlation between different transfer factors and fungal diversity (Table S3).

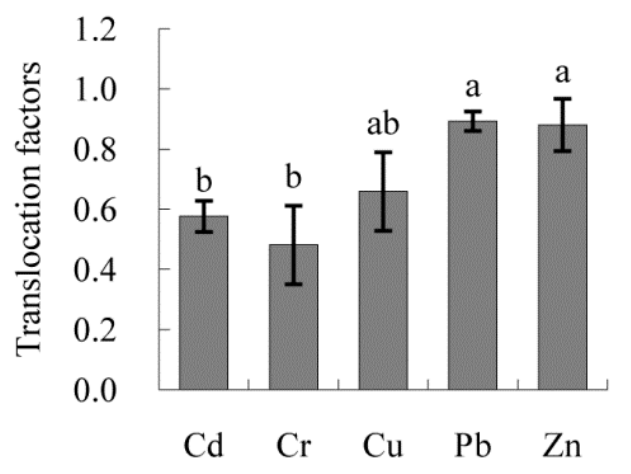

Heavy metals

Figure 7. Transfer factors of different heavy metals in B. ischaemum. The different case letters indicate that the means are significantly different among reclaimed scenario $(P<0.05)$ with Duncan test $(a>a b>$ b).

Table 3. The Pearson correlations among microbial gene abundances and transfer factors of different heavy metals of soil.

\begin{tabular}{ccccccc}
\hline $\begin{array}{c}\text { Log Number of Microbial } r R N A \\
\text { Gene Copies } \mathbf{~ g}^{\mathbf{- 1}} \text { Dry Soil }\end{array}$ & TF-Cd & TF-Cr & TF-Cu & TF-Pb & TF-Zn \\
\hline Non-rhizosphere & Bacteria & -0.130 & -0.069 & -0.013 & -0.718 & -0.155 \\
& Fungi & 0.057 & 0.062 & 0.002 & -0.632 & -0.411 \\
\multirow{2}{*}{ Rhizosphere } & B/F & -0.341 & -0.262 & -0.048 & 0.292 & 0.673 \\
& Bacteria & -0.783 & -0.818 & -0.670 & 0.741 & 0.215 \\
& Fungi & -0.130 & -0.069 & -0.013 & -0.718 & -0.155 \\
& B/F & -0.423 & -0.517 & -0.515 & $0.895^{*}$ & -0.004 \\
\hline
\end{tabular}

* Correlation is significant at the 0.05 level (2-tailed). 
Table 4. The Pearson correlations among soil enzyme activities and transfer factors of different heavy metals of soil.

\begin{tabular}{ccccc}
\hline & Catalase & Urease & Sucrase & Phosphatase \\
\hline TF-Cd & 0.254 & -0.174 & -0.632 & 0.371 \\
TF-Cr & 0.169 & -0.340 & -0.583 & 0.321 \\
$\mathrm{TF}-\mathrm{Cu}$ & -0.139 & -0.738 & -0.297 & -0.005 \\
$\mathrm{TF}-\mathrm{Pb}$ & -0.644 & -0.283 & 0.679 & $-0.900 *$ \\
$\mathrm{TF}-\mathrm{Zn}$ & -0.775 & -0.905 * & 0.614 & -0.636 \\
\hline \multicolumn{5}{c}{ * Correlation is significant at the 0.05 level (2-tailed). }
\end{tabular}

\section{Discussion}

The stoichiometric ratio of environmental elements can reflect the ecological strategies of plants, such as how the $\mathrm{C} / \mathrm{N}$ and $\mathrm{C} / \mathrm{P}$ ratios can reflect the growth rate of plants, as well as reveal the relationships between plant growth rates and plant $\mathrm{N}$ and $\mathrm{P}$ use efficiency [40]. Results from this study showed that the $\mathrm{C} / \mathrm{N}$ ratio differed significantly among roots, shoots, and soil, and the $\mathrm{C} / \mathrm{N}$ ratio in roots was higher than in shoots and soil (Figure 1). Moreover, we only detected chromium $(\mathrm{Cr})$ in $\mathrm{B}$. ischaemum, finding no evidence of $\mathrm{Cr}$ in soil, which indicated that this plant species might have an enrichment impact on Cr. A potential explanation for this is that heavy metals enter the plant and bind to the cell wall or form a heavy metal complex, and then accumulate in the plant without the occurrence of a bioactive detoxification effect [41]. It has been reported that the cell wall of Athyrium yokoscense accumulates a large amount of $\mathrm{Cu}, \mathrm{Zn}$, and $\mathrm{Cd}$, accounting for between $70 \%$ and $90 \%$ of the total cell [42]. Hyperaccumulators are highly selective in heavy metal absorption, where only one or several specific metals are absorbed and enriched [43], such as when the phyllosphere of Alyssum bertolonii initially accumulates nickel (Ni), while poorly accumulating cobalt (Co) and $\mathrm{Zn} \mathrm{[44].}$ In this study, we found that there was a strong negative correlation between carbon (C) and $\mathrm{Cu}$ in the shoots of B. ischaemum (Figure 3) and a significant negative correlation between sulfur (S) and Cd in roots (Figure 3). Thus, we speculated that plant nutrients could affect the absorption capacity of heavy metals.

Phyllosphere microorganisms subjected to a wide range of physicochemical stress that can deviate rapidly through leaching, temperature changes, variations in sunlight exposure, and fluctuations in reactive oxygen species production, and, consequently, in oxidative stress intensity [45]. Epiphytes can develop tolerance and resistance mechanisms against the antimicrobial and immunity compounds that are produced by plant tissues or against competing microorganisms [46]. It reported that most of the bacteria were inhibited by heavy metals, but Sphingomonadaceae had a higher tolerance to heavy metals [6], which was different from our results. We found Pseudomonas and Phytoplasma were the predominant bacteria of phyllosphere at genus level (Figure 5d). Among them, Pseudomonas was a kind of highly diverse microbial population, and was widely distributed in various environments of nature, such as soil, water, plants, and animals, as well as a variety of biological and environmental ecological niche. Phytoplasma mainly causes plant etiolation, clump, flower leaf, etc [33]. We also found that the phyllosphere-inhabiting bacteria of B. ischaemum were Gammaproteobacteria, Mollicutes, and Alphaproteobacteria (Figure 5). The Gammaproteobacteria comprise several medically and scientifically important groups of bacteria. Gammaproteobacteria are photosynthetic and oxidize hydrogen sulfide instead of water, producing sulfur as a waste product, and the Gammaproteobacteria that we found in the phyllospheres could be due to their ability to colonize leaf areas. Some members of Gammaproteobacteria (e.g., Pantoea agglomerans) can produce indole-3-acetic acid (IAA), and the production of IAA has been proven to contribute greatly to the fitness of the phyllosphere during periods of active plant colonization [47]. It has also been reported that Proteobacteria could reduce the toxicity of heavy metals through bioconversion, degrading organic pollutants [48,49]. Thus, we concluded that the dominant phyllosphere bacteria of $B$. ischaemum also contributed to the absorption of heavy metals. 
Physicochemical factors of soil, such as heavy metals, $\mathrm{pH}, \mathrm{N}$, and $\mathrm{S}$ were the key factors that affected the structure of soil bacterial community, for example, Sphingomonadaceae showed certain tolerance to heavy metals [50]. The structure and diversity of the soil microbial community varied in conjunction with the various ecological environmental factors [51], such as $\mathrm{pH}$ [52], heavy metals [53], salinity [54], and the $\mathrm{C} / \mathrm{N}$ [55]. The relationships between microbial communities and habitats can be indicative of specific microbiological groups, which can reflect the response mechanisms of microbial communities to environmental change [6]. This relationship showed that microbial biomass differed in soil that was subjected to heavy metal pollution [56], and different concentrations and types of heavy metals had different effects on soil microbial biomass. We determined that soil physicochemical factors also had an effect on heavy metals; for instance, we found a significant negative correlation between soil $\mathrm{NO}_{3}{ }^{+}-\mathrm{N}$ and As, while soil $\mathrm{N}$ and $\mathrm{Zn}$ were significantly positively correlated. We also found a significantly positively correlation between $\mathrm{S}$ and $\mathrm{Cd}$ in soil (Figure 4). The abundance of bacterial genes in non-rhizosphere soil was higher than that in rhizosphere soil, but the abundance of fungi genes in rhizosphere soil was significantly higher than that in non-rhizosphere soil (Figure 6). These findings indicated that different rhizospheric regions also had different effects on soil bacteria and fungi. These results could be explained by the differences in environmental heterogeneity and microbial interactions [57]. We found that rhizosphere fungi diversity was significantly correlated to phosphatase, and non-rhizosphere fungi diversity was significantly correlated to sucrose enzymes. The reason for this could potentially be that plants have a stronger influence on microbial habitats in the soil [58]. Studies have shown that the composition of root exudates, which mainly serve as $C$ and energy sources for soil microorganisms (especially rhizosphere microbes), strongly influence the structural and functional diversity of microbial communities [59,60].

Under heavy metal stress, microbes can actively change the state of heavy metals in the environment by means of their own metabolic activities, which could improve the soil aggregate structure and properties, while affecting the process of plant root secretion, indirectly influencing heavy metal speciation [61]. According to Fließbach et al. [62], high concentrations of heavy metals lead to a significant decrease in soil microbial biomass, while low concentrations of heavy metals can stimulate microbial growth and increase the overall microbial $\mathrm{C}$ biomass. Soil properties have a certain effect on microbial diversity. We found that soil $\mathrm{S}$ and $\mathrm{Cd}$ were significantly positively correlated to the Shannon-Wiener index and Simpson's Diversity index. Moreover, we also found that soil S, soil bacteria species richness, and Margalef's richness index were significantly positively correlated (Table S2). Ammonium nitrogen, total nitrogen, and $\mathrm{Zn}$ were positively correlated to non-rhizosphere soil fungi diversity, but the $\mathrm{C} / \mathrm{N}$ was significantly negatively correlated to its diversity. This may be due to the steady accumulation of heavy metals in soil, which destroy the natural soil microbial community structure and the activity of the biological community, weakening soil microbial functions, and reducing soil fertility and quality, ultimately changing the distribution of the microbial community [63-65].

\section{Conclusions}

This study discussed the distribution of heavy metals in plants and compared the driving factors between aboveground and subsurface microbial communities, as well as the different response of rhizosphere and non-rhizosphere soil microbial communities to heavy metal transfer factors in a copper tailings dam. We found that $B$. ischaemum had a certain enrichment effect on $\mathrm{Cr}$, particularly the roots, and plant nutrients could affect the absorption capacity of heavy metals. Moreover, we found that the dominant phyllosphere bacteria of B. ischaemum also contributed to the absorption of heavy metals. Soil $\mathrm{S}$ was the main influencing factor of the soil bacterial community, while $\mathrm{NH}_{4}{ }^{+}-\mathrm{N}$, $\mathrm{TN}$, and $\mathrm{Zn}$ were the driving factors for non-rhizosphere soil fungi diversity. Also, rhizosphere fungi diversity was significantly correlated to phosphatase, and non-rhizosphere fungi diversity was significantly correlated to sucrose enzymes. Thus, our study could have important implications in the understanding of the potential ecological function of B. ischaemum in heavy metal accumulation in the 
copper tailings dams. Additionally, our results can aid in the evaluation of the driving factors that affect B. ischaemum bacteria community diversity, which may offer some scientific reference for screening the dominant combinations of bacterial communities as well as improving the plant-microbial remediation efficiency in copper tailings dams.

Supplementary Materials: The following are available online at http:/ / www.mdpi.com/2076-3417/8/9/1419/s1, Table S1: The Pearson correlations among root chemical properties, heavy metals and diversity indices of rhizophere soil microbial community, Table S2: The Pearson correlations among soil physicochemical properties, heavy metals and diversity indices of non-rhizophere soil microbial community, Table S3: The Pearson correlations among transfer factors of different heavy metals and diversity indices of soil microbial community.

Author Contributions: Conceived and designed the experiments: T.J.; performed the experiments: M.C.; analyzed the data: T.J., T.G.; contributed reagents/materials/analysis tools: BC. Wrote the paper: T.J.

Funding: The research was supported by the National Natural Science Foundation of China (grant no. 31600308), Shanxi Province Science Foundation for Youths (grant no. 201601D021101), Shanxi Province Foundation for Returness (grant no. 2016-006).

Conflicts of Interest: The funders had no role in the design of the study; in the collection, analyses, or interpretation of data; in the writing of the manuscript, and in the decision to publish the results.

\section{References}

1. Wang, S.L.; Liao, W.B.; Yu, F.Q.; Liao, B.; Shu, W.S. Hyperaccumulation of lead, zinc, and cadmium in plants growing on a lead/zinc outcrop in Yunnan Province, China. Environ. Geol. 2009, 58, 471-476. [CrossRef]

2. Conesa, H.M.; Faz, A.; Arnaldos, R. Initial studies for the phytostabilization of a mine tailing from the Cartagena-La Union Mining District (SE Spain). Chemosphere 2007, 66, 38-44. [CrossRef] [PubMed]

3. Wong, M.H. Ecological restoration of mine degraded soils, with emphasis on metal contaminated soils. Chemosphere 2003, 50, 775-780. [CrossRef]

4. Jia, T.; Cao, M.W.; Jing, J.H.; Liu, J.X.; Chai, B.F. Endophytic fungi and soil microbial community characteristics over different years of phytoremediation in a copper tailings dam of Shanxi, China. Sci. Total Environ. 2017, $574,881-888$.

5. Deng, H.; Ye, Z.H.; Wong, M.H. Accumulation of lead, zinc, copper and cadmium by 12 wetland plant species thriving in metal-contaminated sites in China. Environ. Pollut. 2004, 132, 29-40. [CrossRef] [PubMed]

6. Liu, J.X.; Li, C.; Jing, J.H.; Jia, T.; Liu, X.G.; Wang, X.Y.; Chai, B.F. Composition and environmental adaptation of microbial community in Shibahe copper tailing in Zhongtiao mountain in Shanxi. Environ. Sci. 2017, 38, 318-326.

7. He, Z.G.; Xie, X.H.; Xiao, S.M.; Liu, J.S.; Qiu, G.Z. Microbial diversity of mine water at Zhong Tiaoshan copper mine, China. J. Basic Microbiol. 2010, 47, 485-495. [CrossRef] [PubMed]

8. Bradshaw, A.D.; Humphreys, M.O.; Johnson, M.S. The value of heavy metal tolerance in the revegetation of metalliferous mine wastes. Environ. Manag. Mineral. Wastes 1978, 311-314. [CrossRef]

9. Marques, A.P.G.C.; Rangel, A.O.S.S.; Castro, P.M.L. Remediation of heavy metal contaminated soils, phytoremediation as a potentially promising clean-up technology. Crit. Rev. Environ. Sci. Technol. 2009, 39, 622-654. [CrossRef]

10. González, R.C.; González-Chávez, M.C.A. Metal accumulation in wild plants surrounding mining wastes. Environ. Pollut. 2006, 144, 84-92. [CrossRef] [PubMed]

11. Bech, J.; Poschenrieder, C.; Barceló, J.; Lansac, A. Plants from mine spoils in the south american area as potential sources of germplasm for phytoremediation technologies. Eng. Life Sci. 2002, 22, 5-11. [CrossRef]

12. Mendez, M.O.; Glenn, E.P.; Maier, R.M. Phytostabilization potential of quailbush for mine tailings. J. Environ. Qual. 2007, 36, 245-253. [CrossRef] [PubMed]

13. Conesa, H.M.; Faz, A.; Arnaldos, R. Heavy metal accumulation and tolerance in plants from mine tailings of the semiarid Cartagena-La Union mining district (SE Spain). Sci. Total Environ. 2006, 366, 1-11. [CrossRef] [PubMed]

14. Gao, Y.J.; Li, J.H.; Jin, D.S.; Lu, J.J.; Gao, C.H.; Zhang, M. Discussion on microbial remediation technology of heavy metal contaminated soil. J. Shanxi Agric. Sci. 2018, 46, 150-154. 
15. Pan, X.; Achal, V.; Zhao, C.X.; Yang, J.Y.; Kumari, D. Microbial remediation of heavy metals and arsenic-contaminated environments in the arid zone of northwest China. In Twenty Years of Research and Development on Soil Pollution and Remediation China; Springer: Singapore, 2018; pp. 477-486.

16. Ojuederie, O.B.; Babalola, O.O. Microbial and plant-assisted bioremediation of heavy metal polluted environments, a review. Int. J. Environ. Res. Public Health 2017, 14, 1504. [CrossRef] [PubMed]

17. Lazaridou, E.; Giannopoulou, C.; Fotiadou, C.; Vakirlis, E.; Trigoni, A.; Ioannides, D. The potential role of microorganisms in the development of rosacea. J. Deutsch. Dermatol. Ges. 2011, 9, 21-25. [CrossRef] [PubMed]

18. Kaschuk, G.; Alberton, O.; Hungria, M. Three decades of soil microbial biomass studies in Brazilian ecosystems, lessons learned about soil quality and indications for improving sustainability. Soil. Biol. Biochem. 2010, 42, 1-13. [CrossRef]

19. Finkenbein, P.; Kretschmer, K.; Kuka, K.; Klotz, S.; Heilmeier, H. Soil enzyme activities as bioindicators for substrate quality in revegetation of a subtropical coal mining dump. Soil. Biol. Biochem. 2013, 56, 87-89. [CrossRef]

20. Dangi, S.R.; Stahl, P.D.; Wick, A.F.; Ingram, L.J.; Buyer, J.S. Soil microbial community recovery in reclaimed soils on a surface coal mine site. Soil Sci. Soc. Am. J. 2012, 76, 915-924. [CrossRef]

21. Claassens, S.; Rensburg, P.J.J.V.; Maboeta, M.S.; Rensburg, L.V. Soil Microbial community function and structure in a post-mining chronosequence. Water Air Soil Pollut. 2008, 194, 315-329. [CrossRef]

22. Li, J.J.; Zhou, X.M.; Yan, J.X.; Li, H.J.; He, J.Z. Effects of regenerating vegetation on soil enzyme activity and microbial structure in reclaimed soils on a surface coal mine site. Appl. Soil Ecol. 2015, 87, 56-62. [CrossRef]

23. Cheng, F.; Peng, X.; Zhao, P.; Yuan, J.; Zhong, C.; Cheng, Y.; Cui, C.; Zhang, S. Soil microbial biomass, basal respiration and enzyme activity of main forest types in the Qinling Mountains. PLoS ONE 2013, 8, e67353. [CrossRef] [PubMed]

24. Bakker, P.A. The rhizosphere microbiome and plant health. Trends Plant Sci. 2012, 17, 478-486.

25. Raaijmakers, J.M.; Paulitz, T.C.; Steinberg, C.; Alabouvette, C.; Moënneloccoz, Y. The rhizosphere, a playground and battlefield for soilborne pathogens and beneficial microorganisms. Plant Soil 2009, 321, 341-361. [CrossRef]

26. Klemedtsson, L.; Svensson, B.H.; Rosswall, T. Relationships between soil moisture content and nitrous oxide production during nitrification and denitrification. Biol. Fertil. Soils 1988, 6, 106-111. [CrossRef]

27. Zhao, Y.; Wu, L.; Chu, L.; Yang, Y.; Li, Z.; Azeem, S.; Zhang, Z.; Fang, C.; Lin, W. Interaction of Pseudostellaria heterophylla with Fusarium oxysporum f.sp. heterophylla mediated by its root exudates in a consecutive monoculture system. Sci. Rep. 2015, 5, 8197. [CrossRef] [PubMed]

28. Elbl, J.; Záhora, J. The comparison of microbial activity in rhizosphere and non-rhizosphere soil stressed by drought. In Proceedings of the Mendel Net 2014, Brno, Czech Republic, 19-20 November 2014; pp. $234-240$.

29. Whipps, J.M.; Hand, P.; Pink, D.; Bending, G.D. Phyllosphere microbiology with special reference to diversity and plant genotype. J. Appl. Microbiol. 2008, 105, 1744-1755. [CrossRef] [PubMed]

30. Chinnadurai, C.; Balachandar, D.; Sundaram, S.P. Characterization of 1-aminocyclopropane-1-carboxylate deaminase producing methylobacteria from phyllosphere of rice and their role in ethylene regulation. World J. Microbiol. Biotechnol. 2009, 25, 1403-1411. [CrossRef]

31. Janarthine, S.R.S.; Eganathan, P. Plant growth promoting of endophytic sporosarcina aquimarina SjAM16103 isolated from the pneumatophores of Avicennia marina L. Int. J. Microbiol. 2012, 2012, 532060. [CrossRef] [PubMed]

32. Balintkurti, P.; Simmons, S.J.; Blum, J.E.; Ballaré, C.L.; Stapleton, A.E. Maize leaf epiphytic bacteria diversity patterns are genetically correlated with resistance to fungal pathogen infection. Mol. Plant-Microbe Interact. 2010, 23, 473-484. [CrossRef] [PubMed]

33. Costa, D.M.D.; Samarasinghe, S.S.T.; Dias, H.R.D.; Dissanayake, D.M.N. Control of rice sheath blight by phyllosphere epiphytic microbial antagonists. Phytoparasitica 2008, 36, 52-65. [CrossRef]

34. Liu, J.; Li, C.; Jing, J.; Zhao, P.; Luo, Z.; Cao, M.; Ma, Z.; Jia, T.; Chai, B. Ecological patterns and adaptability of bacterial communities in alkaline copper mine drainage. Water Res. 2018, 133, 99-109. [CrossRef] [PubMed]

35. Qiao, S.; Zhou, Y.; Liu, J.; Jing, J.; Jia, T.; Li, C.; Yang, X.; Chao, B. Characteristics of soil bacterial community structure in coniferous forests of Guandi mountains, Shanxi province. Sci. Silvae Sin. 2017, 53, 89-99.

36. Li, J.; Liu, F.; Zhou, X. Effects of different reclaimed scenarios on soil microbe and enzyme activities in mining areas. Environ. Sci. 2015, 36, 1836-1841. 
37. Jorquera, M.A.; Maruyama, F.; Ogram, A.V.; Navarrete, O.U.; Lagos, L.M.; Inostroza, N.G.; Acuna, J.J.; Rilling, J.I.; Mora, M.1.1.M. Rhizobacterial community structures associated with native plants grown in Chilean extreme environments. Microb. Ecol. 2016, 72, 633-646. [CrossRef] [PubMed]

38. Bassam, B.J.; Caetanoanollés, G.; Gresshoff, P.M. Fast and sensitive silver staining of DNA in polyacrylamide gels. Anal. Biochem. 1991, 196, 80-83. [CrossRef]

39. Yang, Y.; Song, Y.; Scheller, H.V.; Ghosh, A.; Ban, Y.; Chen, H.; Tang, M. Community structure of arbuscular mycorrhizal fungi associated with Robinia pseudoacacia in uncontaminated and heavy metal contaminated soils. Soil Biol. Biochem. 2015, 86, 146-158. [CrossRef]

40. Niklas, K.J.; Cobb, E.D. N, P, and C stoichiometry of Eranthis hyemalis (Ranunculaceae) and the allometry of plant growth. Am. J. Bot. 2005, 92, 1256-1263. [CrossRef] [PubMed]

41. Nies, D.H.; Silver, S. Plasmid-determined inducible efflux is responsible for resistance to cadmium, zinc, and cobalt in Alcaligenes eutrophus. J. Bacteriol. 1989, 171, 896-900. [CrossRef] [PubMed]

42. Nishizono, H.; Ichikawa, H.; Suziki, S.; Suzuki, S.; Ishii, F. The role of the root cell wall in the heavy metal tolerance of Athyrium yokoscense. Plant Soil 1987, 101, 15-20. [CrossRef]

43. Salt, D.E.; Kramer, U. Mechanisms of metal hyperaccumulation in plants. In Phytoremediation of Toxic Metals: Using Plants to Clean up the Environment; Raskin, I., Ensley, B.D., Eds.; John Wiley \& Sons: New York, NY, USA, 2000; pp. 231-246.

44. Gabbrielli, R.; Mattioni, C.; Vergnano, O. Accumulation mechanisms and heavy metal tolerance of a nickel hyperaccumulator. J. Plant Nutr. 1991, 14, 1067-1080. [CrossRef]

45. Bringel, F.; Couée, I. Pivotal roles of phyllosphere microorganisms at the interface between plant functioning and atmospheric trace gas dynamics. Front. Microbiol. 2015, 6, 486. [CrossRef] [PubMed]

46. Trouvelot, S.; Heloir, M.C.; Poinssot, B.; Gauthier, A.; Paris, F.; Guillier, C.; Combier, M.; Trda, L.; Daire, X.; Adrian, M. Carbohydrates in plant immunity and plant protection, roles and potential application as foliar sprays. Front. Plant Sci. 2014, 5, 592. [CrossRef] [PubMed]

47. Brandl, M.T.; Lindow, S.E. Contribution of indole-3-acetic acid production to the epiphytic fitness of erwinia herbicola. Appl. Environ. Microbiol. 1998, 64, 3256-3263. [PubMed]

48. Teng, Y.; Huang, C.Y. Ecological effect of heavy metals on soil microbes and research advances on the mechanisms of bioremediation. Soil Environ. Sci. 2002, 11, 85-89.

49. Li, X.; Cheng, L.; Deng, Y.; Zhang, H. Advances in anaerobic biodegradation of hydrocarbon. Chin. J. Appl. Environ. Biol. 2008, 14, 283-289.

50. Jing, J.; Liu, J.; Cui, L.I.; Jia, T.; Wang, X.; Chai, B. The structural characteristics of a soil bacterial community in a dam of copper mine tailings in Zhongtiao mountain, Shanxi. Chin. J. Appl. Environ. Biol. 2017, 23, 527-534.

51. Buyer, J.S.; Zuberer, D.A.; Nichols, K.A.; Franzluebbers, A.J. Soil microbial community function, structure, and glomalin in response to tall fescue endophyte infection. Plant Soil 2011, 339, 401-412. [CrossRef]

52. Tripathi, B.M.; Stegen, J.C.; Kim, M.; Dong, K.; Adams, J.M.; Lee, Y.K. Soil pH mediates the balance between stochastic and deterministic assembly of bacteria. ISME J. 2018, 12, 1072-1083. [CrossRef] [PubMed]

53. Li, X.; Meng, D.; Li, J.; Yin, H.; Liu, H.; Liu, X.; Cheng, C.; Xiao, Y.; Liu, Z.; Yan, M. Response of soil microbial communities and microbial interactions to long-term heavy metal contamination. Environ. Pollut. 2017, 231, 908-917. [CrossRef] [PubMed]

54. Wichern, J.; Wichern, F.; Joergensen, R.G. Impact of salinity on soil microbial communities and the decomposition of maize in acidic soils. Geoderma 2006, 137, 100-108. [CrossRef]

55. Liu, H.M.; Zhang, H.F.; Huangfu, C.H.; Jie, L.I.; Zhou, G.F.; Yang, D.L. Effects of different long-term nitrogen addition on soil microbial diversity of Stipa baicalensis steppe in Inner Mongolia, China. J. Agro-Environ. Sci. 2017, 36, 709-717.

56. Wang, Y.; Shi, J.; Wang, H.; Lin, Q.; Chen, X.; Chen, Y. The influence of soil heavy metals pollution on soil microbial biomass, enzyme activity, and community composition near a copper smelter. Ecotoxicol. Environ. Saf. 2007, 67, 75-81. [CrossRef] [PubMed]

57. Hunter, P.J.; Hand, P.; Pink, D.; Whipps, J.M. Both leaf properties and microbe-microbe interactions influence within-species variation in bacterial population diversity and structure in the lettuce (Lactuca Species) phyllosphere. Appl. Environ. Microbiol. 2010, 76, 8117-8125. [CrossRef] [PubMed] 
58. Dohrmann, A.B.; Tebbe, C.C. Effect of elevated tropospheric ozone on the structure of bacterial communities inhabiting the rhizosphere of herbaceous plants native to Germany. Appl. Environ. Microbiol. 2005, 71, 7750-7758. [CrossRef] [PubMed]

59. Schmalenberger, A.; Tebbe, C.C. Genetic profiling of noncultivated bacteria from the rhizospheres of sugar beet (Beta vulgaris) reveal field and annual variability but no effect of a transgenic herbicide resistance. Can. J. Microbiol. 2003, 49, 1-8. [CrossRef] [PubMed]

60. Kögel-Knabner, I. The macromolecular organic composition of plant and microbial residues as inputs to soil organic matter. Soil Biol. Biochem. 2002, 34, 139-162. [CrossRef]

61. Shi, X.; Chang, X. Microbial responses to heavy metal pollution in soils. Ecol. Environ. 2003, 12, $498-499$.

62. Fließbach, A.; Martens, R.; Reber, H.H. Soil microbial biomass and microbial activity in soils treated with heavy metal contaminated sewage sludge. Soil Biol. Biochem. 1994, 26, 1201-1205. [CrossRef]

63. Zhang, J.; Zhou, Y.; Mai, Y.E.; Dou, L.; Li, X.Y.; Mo, L.P. Bioavailability of heavy metal and transfer factors in a regional soil-to-crops system. Environ. Sci. Technol. 2017, 40, 256-266.

64. Zhao, Y.; Ma, Z.J.; Zhang, X.; Xue, X.; Li, M.Y.; Cheng, Y.W.; Zha, T.G. Influencing factors of heavy metal mobility and evaluating methods of heavy metal bioavailability in soil-plant system. J. Chin. Inst. Water Resour. Hydropower Res. 2015, 13, 177-183.

65. Olaniran, A.O.; Adhika, B.; Balakrishna, P. Bioavailability of heavy metals in soil, impact on microbial biodegradation of organic compounds and possible improvement strategies. Int. J. Mol. Sci. 2013, 14, 10197-10228. [CrossRef] [PubMed]

(C) 2018 by the authors. Licensee MDPI, Basel, Switzerland. This article is an open access article distributed under the terms and conditions of the Creative Commons Attribution (CC BY) license (http:/ / creativecommons.org/licenses/by/4.0/). 